MIMBAR

JURNAL PENELITIAN SOSIAL DAN POLITIK

\title{
KAPASITAS ORGANISASI DALAM PENGEMBANGAN PARIWISATA DESA: STUDI KASUS DESA WISATA KABUPATEN BINTAN
}

\section{Oleh :}

\author{
Okparizan *, Asep Sumaryana, Didin Muhafidin, Yogi Suprayogi Sugandi \\ *Korespondensi Email : okparizan1500@mail.Unpad.ac.id \\ Program Doktor Administrasi Publik Fakultas Ilmu Sosial dan Ilmu Politik \\ Universitas Padjajaran Bandung
}

\begin{abstract}
ABSTRAK
Kinerja organisasi desa belum optimal dalam memaksimalkan potensi desa wisata. Hal ini mengakibatkan desa wisata belum memberikan kontribusi positif pada pembangunan desa. Indikator yang menjadi tolok ukur belum optimalnya kinerja lembaga desa adalah belum terwujudnya tiga sasaran pengembangan pembangunan desa yaitu atraksi wisata, aksesibilitas dan amenitas. Penelitian ini dilakukan untuk menganalisis bagaimana mewujudkan kapasitas organisasi desa yang efektif. Penelitian ini menggunakan pendekatan kualitatif bersifat deskriptif interpretatif, dengan subjek penelitian empat desa wisata yaitu Desa Sungai Kecil, Desa Sebong Pereh, Desa Pengudang, dan Desa Berakit. Data yang digunakan yaitu data primer melalui wawancara yaitu dengan tanya jawab berdasarkan daftar pertanyaan dan wawancara tidak terstruktur serta observasi untuk melihat langsung realitas yang terjadi di locus penelitian. Data selanjutnya yang digunakan yaitu data sekunder dari dokumen pendukung. Hasil dari analisis penelitian empiris membuktikan dimensi kapasitas organisasi cenderung tidak memberikan manfaat yang lebih besar dalam pembangunan di desa wisata. Keseluruhan dimensi kapasitas yang dinilai tidak menunjukkan dukungan kapasitas kerja yang efektif. Implikasi dari hasil temuan penelitian dan dokumentasi yang dilakukan menghasilkan kesimpulan bahwa Human resorcus, Eksternal, infrastructure dan Financial dalam linkungan organisasi desa belum memiliki kualitas yang mencukupi untuk mendukung secara efektif terlaksana pembangunan kepariwisataan di empat desa wisata.
\end{abstract}

Kata Kunci : Desa, Kapasitas Organisasi, Wisata 
MIMBAR

JURNAL PENELITIAN SOSIAL DAN POLITIK

\section{A. Pendahuluan}

Desa secara normatif digerakkan melalui undang-undang desa, demikian juga struktur organisasi yang menggerakkannya sudah disesuaikan dengan fungsi masingmasing.

Langkah responsif pemerintah untuk menghasilkan kesejahteraan masyarakat yaitu melalui pembangunan desa dan mendorong pembangunan berkelanjutan. Unsur pendukung tercapainya tujuan pembangunan desa berupa komponenkomponen lembaga-lembaga di desa yang menjalin kejasama sebagai bentuk aktivitas dari pemerintahan desa.

Namun masih banyak komponen desa yang kurang berkemampuan untuk menggerakkan pembangunan di desa. Indonesia memiliki setidaknya 74.093 desa, dimana dari jumlah tersebut sekitar 33.592 atau $45.57 \%$ berstatus tertinggal dan 13.453 atau $18.25 \%$ bersetatus sangat tertinggal (http://www.kemdesa.id/, 29/04/2018).

Faktor penting dalam pembangunan desa diantaranya sumber daya manusia (pengetahuan dan keahlian), dan tingkat operasionalisasi yang dimiliki organisasi desa. Identifikasi awal menunjukkan terdapat beberapa permasalahan terkait pembangunan di desa Salah satu faktor tidak berhasilnya pembangunan dikarenakan masih lemahnya kapasitas yang dimiliki pemerintahan desa. Makna dari lemahnya kapasitas dimaksud sering dihubung kaitkan dengan kapasitas organisasi untuk mempertahankan visi, menimbulkan budaya yang berorientasi kegiatan menegakkan ketegasan dan akuntabilitas, untuk melibatkan para pemangku kepentingan, dan untuk mempertahankan fleksibilitas dalam cara-cara itu mencapai dukungan keuangan, memenuhi tujuan-tujuan program, menanggapi masyarakat kebutuhan, dan diversifikasi dan memanfaatkan sumber daya (York, 2010).

Masalah selanjutnya berupa ketidak mandirian desa dalam mengelola sumber daya. Ketidakmandirian yang muncul dikarenakan intervensi keputusan dan kebijakan pemerintah supra di atasnya yang belum tentu sesuai dengan kapasitas lembaga desa akibatnya motivasi untuk menjalankan misi tersebut belum teraktualisasi . Pembangunan desa juga dipengaruhi dampak teknis dari operasionalisasi organisasi desa diantaranya dukungan sumber daya yang kurang dan tingkat kepercayaan lingkungan kerja yang rendah.

Organisasi desa juga belum dapat menggerakkan masyarakat menjadi salah satu kekuatan penting dalam proses pembangunan salah satunya pada pembangunan kepariwisatan di desa wisata di Kabupaten Bintan. Pembangunan kepariwisataan di desa meskipun sudah diberikan kewenangan mengelola potensi wisata, motivasi untuk menjalankan misi tersebut belum teraktualisasi, baik dalam perencanaan anggaran dan aktualisasi kegiatan-kegiatan kepariwisataan di desa.

Terbangunnya atraksi wisata, aksesabilitas dan amenitas dapat digunakan sebagai sumber informasi untuk melihat sejauhmana organisasi desa melakukan pembangunan kepariwisataan sesuai potensi yang tersedia. Kewenangan dalam mengelola pembangunan desa, eksistensi masyarakat dan organisasi desa harus di tingkatkan sehingga kemampuan perencanaan dan pelaksanaan pembangunan dapat terpolarisasi dengan baik sesuai dengan dorongan pembangunan di desa.

Penelitian tentang tingkat kapasitas organisasi desa perlu dilakukan untuk mengidentifikasi persoalan-persoalan di desa wisata. Pentingnya pembahasan tentang kapasitas sesuai dengan pendapat bahwa salah satu kekuatan penting dalam proses pembangunan adalah kemampuan menggerakkan masyarakat. Beberapa penelitian yang komprehensif telah dilakukan peneliti sebelumnya diantaranya, Horton, et al., (2013) mengidentfikasi penilaian kapasitas pada ruang lingkup dimensi sumber daya dasar meliputi staf, infrastruktur, teknologi, pembiayaan, pengetahuan dan proses yang dilakukan organisasi, kapasitas manajemen dalam organisasi meliputi kepemimpinan strategis, program, proses manajemen, jejaring dan keterkaitan. Christensen dan Gazley (2008) dalam studinya memberikan penilaian kapasitas pada ruang lingkup dimensi infrastruktur organisasi, sumber daya manusia, sumber infrastruktur, keuangan, lingkungan eksternalitas.

Lebih lanjut, beberapa publikasi yang telah meletakkan dasar pemahaman kapasitas organisasi sektor pariwisata secara 
komprehensif seperti, Roxas et.al (2013) dalam studinya menemukan bahwa peran penting pemerintah dalam memastikan lingkungan organisasi formal dapat mempromosikan dan meningkatkan kinerja sektor pariwisata. Fong Wong dan Hong (2018) menemukan bahwa perubahan logika praktik para pemangku kepentingan dan lingkungan organisasi di sekitarnya dapat mempengaruhi kapasitas organisasi. Wibawati (2015) mengemukakan pada lingkup analisis pengembangan potensi parwisata berbasis masyarakat yang dapat di operasionalisasi melalui tataran individual, tersistem dan organisasi.

Meskipun sudah ada pembahasan yang komprehensif tentang kapasitas organisasi sektor pariwisata dari beberapa studi terdahulu, namun terdapat pertanyaan seperti apakah pengelolaan organisasi akan menghasilkan analisis yang sama dari semua bentuk organisasi serta perhatian terhadap unsur kearifan lokal disetiap daerah yang mempengaruhi aktivitas lembaga perlu menjadi perhatian tersendiri. Untuk itu, tujuan penulisan artikel ini adalah menganalisis kapasitas organisasi lokal (desa) dan juga memperhatikan kearipan lokal yang dapat mempengaruhi kapasitas organisasi desa pada sektor pariwisata.

\section{B. Metode Penelitian}

Penelitian ini menggunakan pendekatan kualitatif bersifat deskriptif interpretatif, dengan subjek penelitian empat desa wisata yaitu Desa Sungai Kecil, Desa Sebong Pereh, Desa Pengudang, dan Desa Berakit. Data yang digunakan yaitu data primer melalui wawancara yaitu dengan tanya jawab berdasarkan daftar pertanyaan dan wawancara tidak terstruktur serta observasi untuk melihat langsung realitas yang terjadi di locus penelitian. Data selanjutnya yang digunakan yaitu data sekunder dari dokumen pendukung. Data primer diambil tahun 2017-2018.

\section{Hasil Penelitin dan Pembahasan}

Desa wisata yang menjadi lokus penelitian dibentuk berdasarkan Keputusan Kepala Dinas Pariwisata Kabupaten Bintan Nomor 14a/SK/DISPARBUD/2017 Tentang Pembentukan Desa Wisata di Kabupaten Bintan. Desa wisata dalam penelitian ini berada pada satu wilayah Kecamatan Telok Sebong dan desa wisata dimaksud adalah Desa Sungai Kecil, Desa Pengudang, Desa
Sebong Pereh dan Desa Berakit. Pembentukan Desa wisata merupakan program penting pemerintah daerah untuk memanfaatkan posisi strategis kepariwisataan di Kabupaten Bintan, sebagaimana disebutkan dalam RIPPARDA Kabupaten Bintan Tahun 2015-2025.

Desa wisata di Kabupaten berada disepanjang area wilayah pesisir pantai, memiliki berberapa daya tarik alami yang dapat dikemas untuk berbagai aktivitas berwisata, seperti kegiatan wisata bahari dan eko wisata. Karakteristik desa wisata yang ada mencerminkan wilayah perdesaan yang bisa dikembangkan dan memiliki nilai strategis produk kepariwisataan. Desa wisata yang ada sudah teridentifikasi memiliki daya tarik Sumber Daya Alam (SDM) sebagai modal dasar pengembangan kepariwisataan.

Dalam melihat secara komprehensif kapasitas organisasi di 4 desa wisata tersebut, dari konsep teoritis dapat dinilai dalam 4 (empat) dimensi kapasitas diungkapkan Christensen \& Gazley (2008) yaitu: 1) Human Resources); 2) External; 3) Infrastructure; dan 4) Financial

\section{a. Human Resources}

Hasil penelitian sumber daya manusia di empat desa wisata memperlihatkan masih perlunya tambahan ilmu dan pengetahuan sebagai upaya menjembatani kesenjangan pada unsur ketersediaan pendidikan formal dengan pengetahuan personil menjalankan pemeritahan yang masih terbatas. Hal ini didasari pada informasi bahwa potensi kemampuan akademis para personil di masing-masing organisasi (pemerintah desa, lembaga BPD) masih banyak berlatar belakang pendidikan SMA/Sederajat sehingga dengan tuntutan pekerjaan pemerintahan desa yang cukup komplek, SDM yang demikian akan berpengaruh pada kapasitas kinerja yang dihasilkan.

Selain itu keempat desa wisata belum terfasilitasi pada kegiatan memperoleh pengetahuan dalam pembangunan kepariwisataan di desa karena keberadaan desa wisata di Kabupaten Bintan belum terkomunikasi dan tersosialisasi dengan sejumlah Satuan Kerja Perangkat Daerah (SKPD) lainnya, hasil wawancara Sekretaris DPMD Kabupaten Bintan menegaskan 
permasalahan tersebut.

"Selama ini belum pernah mendapatkan informasi terkait keberadaan desawisata di Kabupaten Bintan sehingga kami tidak bias melakukan dukungan program yang tepat sasaran terutama untuk penguatan personil organisasi desa wisata yang selama ini memang belum dijalankan",

Pelatihan-pelatihan yang untuk perangkat desa belum ada yang menyentuh bidang pariwisata. Selain itu peranan DISPAR Kabupaten Bintan belum signifikan untuk menfasilitasi SKPD lainnya untuk mendukung perencanaan pembangunan kepariwisataan di desa wisata. Hal itu ditegaskan oleh Dinas Pariwisata Kabupaten Bintan :

"Selama ini mungkin terjadi miskomunikasi terkait pembentukan desa wisata. Kami berharap Kepala desa dapat secara langsung melakukan koordinasi ke SKPD untuk menyelengarakan hal-hal dianggap perlu demi pembangunan di desa wisata tugas kami hanya melakukan pembinaan" (wawancara Kabid. Destinasi dan Objek wisata DISPAR Kab. Bintan 2018).
Tabel.1.

Kegiatan Peningkatan Kapasitas Sumber Daya Manusia

\begin{tabular}{|c|c|c|}
\hline No & Nama Kegiatan & Pelaksana \\
\hline 1 & $\begin{array}{l}\text { Pelatihan Koperasi } \\
\text { dan Kewirausahaan }\end{array}$ & $\begin{array}{l}\text { Dinas Koperasi dan } \\
\text { UMKM }\end{array}$ \\
\hline 2 & $\begin{array}{l}\text { Bimbingan Teknis } \\
\text { Pengelolaan } \\
\text { Keuangan Desa }\end{array}$ & DPMD Kab.Bintan \\
\hline 3 & $\begin{array}{l}\text { Bimbingan Teknis } \\
\text { Pengelolaan } \\
\text { Keuangan BUMDes }\end{array}$ & DPMD Kab.Bintan \\
\hline 4 & $\begin{array}{l}\text { Bimbingan Teknis } \\
\text { Untuk Pengurus BPD }\end{array}$ & DPMD Kab.Bintan \\
\hline 5 & $\begin{array}{l}\text { Pelatihan } \\
\text { Peningkatan } \\
\text { Kapasitas Aparatur } \\
\text { Pemerintah Desa } \\
\text { Bagi Kepala Desa }\end{array}$ & Biro Pembangunan \\
\hline 6 & $\begin{array}{l}\text { Pelatihan } \\
\text { Peningkatan } \\
\text { Kapasitas Kaur } \\
\text { Pembangunan Desa }\end{array}$ & DPMD Kab.Bintan \\
\hline 7 & $\begin{array}{l}\text { Sosialisasi dan } \\
\text { Bimbingan Teknis } \\
\text { Penyusunan Laporan } \\
\text { ADD desa }\end{array}$ & $\begin{array}{l}\text { Badan Pengawas } \\
\text { Keuangan dan } \\
\text { Pembangunan, } \\
\text { berkerjasama } \\
\text { dengan DPMD } \\
\text { Kab.Bintan }\end{array}$ \\
\hline 8 & $\begin{array}{l}\text { Bimbingan Teknis } \\
\text { penerapan Aplikasi } \\
\text { Sistem Keuangan } \\
\text { Desa (SESKEUDES) }\end{array}$ & DPMD Kab.Bintan \\
\hline 9 & $\begin{array}{l}\text { Bimbingan Teknis } \\
\text { Bagi Tenaga } \\
\text { Pendamping Desa }\end{array}$ & DPMD Kab.Bintan \\
\hline 10 & $\begin{array}{l}\text { Bimbingan Teknis } \\
\text { Bagi RT/RW Se- } \\
\text { Kabupaten Bintan }\end{array}$ & $\begin{array}{l}\text { DPMD Kab.Bintan } \\
\text { bekerjsama dengan } \\
\text { PemerintahDesa }\end{array}$ \\
\hline
\end{tabular}

Sumber Data olahan bedarakan hasil penelitian Tahun 2018

\section{b. Networking}

Networking yang didirikan harus mengakomodasi dan mengkoordinasikan kolaborasi diantara semua pemangku kepentingan. Networking Mengakomodasi 
kewenangan antar pemangku kepentingan secara proporsional melalui sarana pendirian kolaborasi yang efektif (Muzwardi, 2015).

Jaringan kerja (networking) juga dapat dinilai dari adanya tindakan Kepala desa dalam bentuk komunikasi dan koordinasi program dengan pemerintah daerah. Sekretaris DISPAR Kabupaten Bintan mengatakan selama ini pemerintah desa wisata belum pernah berkomunikasi atau istilah lainnya menjemput bola untuk menyesuaikan kegiatan atau mendapatkan dukungan program-program yang bisa dijalankan secara bersama-sama.

\section{c. Exsternal}

Dalam penelitian ini hubungan lingkungan luar mempengaruhi kinerja organisasi desa wisata. Unsur eksternalitas diarahkan pada kegiatan pemerintahan partisipatif (participatory governance) karena pemerintah desa memiliki kosekuansi logis untuk meyediakan sarana dalam melibatkan individu dan organisasi diluar struktur pemerintahan agar dapat mendukung kinerja pembangunan desa

\section{d. Partisipasi Masyarakat}

Partisipasi masyarakat dimaknai sebagai upaya yang dilakukan oleh warga setempat melalui kapasitas institusi pemerintah desa dan emansipasi warga yang dimiliki agar mampu mendayagunakan kemampuan, prakarsa/ inisiatif dan gerakan desa secara kolektif (bekerja sama) dalam mengembangkan sumber-sumber potensiaset daerah yang dimiliki baik fisik maupun non fisik sebagai desa wisata yang dimilikinya (Fajar Sidik, 2015).

Hasil penelitian mendeskripsikan bahwa pemerintah desa belum memiliki keseriusan dan keinginan yang kuat dan serius untuk melibatkan partisipasi masyarakat. Hal tersebut dibuktikan informasi di level pemerintah daerah tidak disalurkan ke masyarakat, sehingga masyarakat belum mengetahui secara jelas arah dari pelaksanaan pembangunan desa berbasis wisata. Pernyataan kurangnya keterlibatan masyarakat ditegaskan tokoh masyarakat :

"Kalau partisipasi untuk terlibat dalam pembangunan saya rasa belum memberikan cukup ruang yang nyata. Biasanya dalam proses pengerjaan pembangunan memang banyak secara swakelola namun kenyataannya hanya sekelmpok individu tertentu yang dikoordinir aparatur pemerintah desa"

Selain itu, dukungan sebagai bentuk keterlibatan dan partisipan masyarakat guna mendorong pencapaian tujuan desa wisata juga tidak dimengerti masyarakat.

Kebijakan penetapan desa wisata merupakan kepentingan daerah, dan desa secara organisasi belum siap menerima karena berbagai alasan contohnya karena faktor kualitas dan kuantitas personil serta rujukan terkait aktivitas yang berhubungan dengan pebangunan desa wisata yang belum dipahami baik oleh pemerintah desa sendiri" (wawancara dengan Kades Desa Sebong Pereh, 11/09/2018)

Kondisi yang demikian, menggambarkan bahwa pemerintahan desa belum berkeinginan dan mampu untuk mentransfer pengetahuan sehingga peran partisipan masyarakat dalam mensukseskan agenda pembangunan pariwisata daerah di desa tidak terlaksana.

\section{e. Infrastructure}

Dalam lingkungan organisasi pemerintahan desa. infrastruktur diarahkan pada terpenuhinya fasilitas kerja (sarana dan prasarana kerja) di lingkungan pemerintahan desa. Dalam berberapa kasus fasilitas kerja yang belum didukung oleh kemampuan oprasionalisasi kerja yang baik belum berhasil menciptakan kinerja yang efektif dan efisien (Lupiyoadi, 2006; Haynes, 2008).

\section{f. Pemanfaatan Teknologi}

Penelitian mendeskripsikan bahwa para personil organisasi desa belum memiliki kemampuan yang cukup untuk mengoperasionalkan sarana teknologi yang tersedia dikarenakan keterbatasan pengetahuan dan minimnya keahlian. Hal demikian berdampak pada belum meningkatnya performance kerja yang dihasilkan di masing-masing organisasi. Berberapa Personil di Kantor Desa Sungai Kecil dan Desa Berakit mendeskripsikan informasi bahwa aktivitas penggunaan komputer masih sebatas pada urusan adminisitrasi dan ada berberapa dokumen 
yang masih dikerjakan secara manual dan belum tertata rapi.

Berdasarkan proses penggalian informasi dan dokumentasi, terkait dengan pemanfaatan teknologi di masing-masing organisasi desa memperlihatkan situasi: 1) Personil organisasi desa belum mampu mengoperasikan sarana teknologi informasi secara baik sebagai sarana mempercepat dan mempermudah dalam berkerja dan mampu menghasilkan inovasi-inovasi dari perkerjaan; 2) Para pimpinan belum memiliki upaya dalam memperbaiki situasi terkait keterbatasan personil dalam memanfaatkan teknologi sebagai sarana komunikasi, informasi dan koordinasi. Permasalahan terkait teknologi ditegaskan oleh perangkat desa.

Tidak semua dokumen dikerjakan dengan dukungan komputer, para personil juga masih ada yang belum bisa mengoperasikan komputer meskipun penata usaha dengan komputerisasi dianggap hal penting terutama pada kegiatan pengarsipan dokumen agar bisa tertata rapi (Sekretaris Desa Sungai Kecil, 26/07/2018)

Memperhatikan hasil dari berberapa temuan terkait pemanfaatan teknologi yang terlihat di masing-masing organisasi desa, dapat mempengaruhi tercapainya produktivitas dan keberhasilan pembangunan kepariwisataan desa.

\section{g. Financial}

Semua pemangku kepentingan yang terlibat harus memahami prinsip-prinsip pengelolaan keuangan di tingkat lokal. dilakukan secara tertib, law biding, efisien, ekonomis, efektif, transparan dan bertanggung jawab dengan mempertimbangkan prinsip-prinsip keadilan, keadilan, dan bermanfaat bagi masyarakat (Darmi, 2018).

Pemerintah desa sebagai pengelolaan keuangan di tingkat lokal harus memahami pengelolaan keuangan dalam pengembangan potensi wisata dengan memanfaatkan potensi sumber daya desa secara mandiri mengelola keuangan desa, baik berupa pendapatan dan maupun aset yang melekat dan disertakan kewajiban dalam rangka menyelengarakan pemerintah desa yang dapat dinilai dengan uang dan kekayaan (Nurcholis, 2011). Terkait dimensi keuangan dalam minilai kapasitas organisasi desa, instrumen penilaian dimaksud, antara lain: (1) Pendapatan Desa; (2) Perencanaan keuangan; dan (3) Inventarisasi dan aset.

\section{h. Pendapatan Desa}

Berdasarkan hasil penelitian dan dokumentasi di empat desa wisata, struktur anggaran dalam APBDes sebagian besar bersumber dari anggran APBN. Hasil identifikasi mendeskripsikan bahwa pengelolaan anggaran di dua tahun terakhir masih memperlihatkan ketimpangan perencanaan. Hal demikian terlihat dari dominasi anggaran pada sejumlah kegiatan pembangunan desa yang masih mengutamakan pembangunan insfrastruktur fisik dan urusan penyelenggaraan pemerintahan. Kegiatan-kegiatan lainnya yang bersifat pemberdayaan masyarakat dan kemasyarakatan belum signifikan teragendakan. Hal tersebut terjadi akibat penganggaran yang terlihat kaku pada urusan pembangunan infrastruktur fisik. Sedangkan kegiatan pemberdayaan dan kemasyarakatan juga belum mendorong terciptanya aksi dan atraksi penguatan ekonomi masyarakat.

Tabel. 2.

Alokasi Dana Desa di 4 DesaWisata

\begin{tabular}{|l|c|c|c|c|c|}
\hline Nama Desa & Alokasi DD & $\begin{array}{c}\text { Pembangunan } \\
\text { Fisik }\end{array}$ & $\begin{array}{c}\text { Urusana } \\
\text { Pemerintahan }\end{array}$ & $\begin{array}{c}\text { Pemberdayaan } \\
\text { Masvarakat }\end{array}$ & $\begin{array}{c}\text { Kegiatan } \\
\text { Nasvarakat }\end{array}$ \\
\hline Sungai Kecil & $895,840,000$ & $539,440,000$ & $201,050,000$ & $73,000,000$ & $76,900,000$ \\
\hline Pegudang & $953,840,000$ & $595,540,000$ & $218,800,000$ & $75,000,000$ & $64,500,000$ \\
\hline SebongPereh & $821,196,000$ & $526,396,000$ & $207,500,000$ & $83,000,000$ & $41,800,000$ \\
\hline Berakit & & & & & \\
& $1,010,335,000$ & $652,534,500$ & $242,800,000$ & $59,000,000$ & $56,000,500$ \\
\hline
\end{tabular}

\section{Sumber: Data olahan 2018}

Empat Desa wisata tersebut di tahun 2017 mendapatkan total alokasi Dana Desa (DD) sebesar Rp. 3,681,211,000 dimana prioritas pengunaan angaran untuk pembangunan fisik sebesar Rp. 2,313,910,500, kemudian untuk penyelenggaraan urusan pemerintahan sebesar Rp. 870,750,000, sedangkan untuk kegiatan pemberdayaan masyarakat sebesar Rp. 290,000,000 dan kegiatan kemasyarakatan Rp. 239,200,500. Data pada Tabel 2 memperlihatkan skala prioritas dana desa di 4 desa wisata masih terkosentrasi di 


\section{MIMBAR}

JURNAL PENELITIAN SOSIAL DAN POLITIK

pembangunan fisik sementara pembangunan sumberdaya manusia melalui pemberdayaan masyarakat masih menjadi skala terbawah.

\section{i. Perencanaan Keuangan}

Berdasarkan hasil penelitian terkait perencanaan keuangan di empat desa wisata memperlihatkan situasi: 1) Bahwa dari sisi pendanaan kegiatan pembangunan di desa sudah tersedia, namun demikian lemahnya pemahaman terkait mekanisme penyusunan anggaran menampilkan ketidak seimbangan antara konsep-konsep pembangunan yang menjadi prioritas terutama dalam pengunaan dana desa; 2) Perencanaan keuangan atau sistem manajemen pengelolan dana desa, belum efektif berjalan, meskipun dalam melakukan perkerjaan mekanisme dan prosedur yang benar belum berjalan, situasi ini mungkin menjadi koreksi kedepan agar lebih diperhatikan sehingga tidak timbul persolan dikemudian hari. 3) Pendampingan yang diberikan belum memberikan kontribusi positif bagi penguatan organisasi di masing-masing desa terutama dalam upaya mendukung profesionalisme dan efektivitas kinerja organisasi.

\section{j. Pengelolaan Aset dan Inventarisasi}

Berdasarkan hasil penelitian di empat desa wisata, pada proses perencanaan pengelolaan aset desa mendeskripsikan informasi bahwa pendokumentasian aset dalam laporan kinerja pemerintah di masingmasing desa sudah dilaksanakan. Namun demikian, hasil penelusuran memperlihatkan produktivitas dari berberapa aset yang ada belum dimaksimalkan terutama sebagai ruang baru yang potensial mendatangkan keuntungan bagi desa.

\section{Kesimpulan dan Saran}

Hasil dari analisis penelitian empiris membuktikan dimensi kapasitas organisasi cenderung tidak memberikan manfaat yang lebih besar dalam pembangunan di desa wisata. Keseluruhan dimensi kapasitas yang dinilai tidak menunjukkan dukungan kapasitas kerja yang efektif.

Pada dimensi Human resources di indentifkasi dari sisi pengetahuan melalui pendidikan formal personil belum medukungan kinerja organisasi desa. Motivasi untuk memperkuat pengetahuan dan skill sesuai kebutuhan pembangunan desa wisata belum terfasilitasi secara baik sehingga belum berhasil meningkatkan performance dan produktivitas kerja. Political will pemerintah desa wisata untuk menyediakan kegiatan dimkasud dalam bentuk pengalokasian kegiatan secara mandiri dalam APBDes juga belum dijalankan. Perhatian pada terpenuhinya kebutuhan dasar (kompensasi dan penghargaan) belum berhasil membangun semangat kerja dalam organisasi desa wisata. Pada proses rekrutmen dan penempatan personil pada jabatan stuktural belum memperhatikan prinsip the right man on the right place sehingga kualitas dan kuantitas personil belum memunculkan produktivitas kerja, misalnya terlihat pada situasi kemampuan manajerial dan prilaku kerja (kepala desa dan aparatur desa) yang tidak disiplin. Pengawasan kinerja yang semestinya dijalankan oleh Lembaga BPD untuk hal demikian tidak terjadi, sehingga menampilkan kinerja organisasi yang belum efektif. Kemudian situasi kepemimpinan/ manajemen kepemimpinan memperlihatkan ketidak berhasilan terutama pada tindakan penentuan keputusan strategis menata oprasional organisasi desa wisata. Gaya kepemimpinan otoriterisasi menghambat berbagai proses komunikasi dan networking dalam pembangunan kepariwisataan di desa wisata.

Pada dimensi External di indentifkasi belum terlihat berjalan kegiatan partisipasi masyarakat secara terbuka (Inclusion). Penglibatan secara efektif pada aktivitas merencanakan dan pembuatan keputusan pada tingkat desa tidak menampilkan kedudukan strategis, sehingga hasil pembangunan belum menampilkan programprogram pembangunan desa wisata yang lebih produktif. Keikutsertaan (Involvement) masyarakat dalam proses kebijakan pembangunan desa wisata masih pasif, misalnya terlihat pada komunikasi pemerintah desa dengan masyarakat untuk mendukung langsung proses pelaksanaan pembangunan desa wisata. Kebijakan tingkat lokal tidak menunjukkan dukungan konsistensi terhadap pemanfaatan SDA pariwisataan.

Pada dimensi infrastructure di identifkasi kegiatan pemanfaatan teknologi, para personil belum berkemampuan secara 
baik mengoperasikan sarana teknologi sehingga proses kerja yang efektif dan efisen belum terlaksana. Upaya untuk memperbaiki situasi demikian belum intensif dilakukan dalam lingkup pemerintahan desa wisata. Selain itu pengintegerasian kerja yang baik pada masing-masing tingkat masih dipengaruhi minimnya dukungan para pimpinan tingkat manajerial. Lembaga BPD memiliki integritas secara kolektif, meskipun kemampuan sumber daya terbatas.

Pada demensi financial di identifkasi bahwa sudah memiliki pendapatan secara memadai untuk menggerakkan proses operasional dan kegiatan pembangunan di desa wisata secara mandiri. Namun demikian kapasitas pada proses perencanaan keuangan terindentifkasi masih lemahnya seperti tidak tertatanya penggunaan anggaran dengan memunculkan ketidak seimbangan pembangunan prioritas sesuai dengan misi pembangunan desa wisata. Berikutnya, sarana pendampingan eksternal belum menunjukkan kontribusi positif dalam penguatan organisasi karena lebih terfokus pada kegiatan pembuatan pelaporan dan dokumentasi.

\section{DAFTAR PUSTAKA}

Christensen, R. K., \& Gazley, B. (2008). Capacity For Public Administration: Analysis Of Meaning. Public Administration And Development, 28 , 265-279.

Dinas Pariwisata Kabupaten Bintan. 2015. Rencana Induk Pembangunan Pariwisata Kabupaten Bintan Tahun 2014-2025.

Fajar Sidik. (2015). Menggali Potensi Lokal Mewujudkan Kemandirian Desa. Jurnal Kebijakan Dan Administrasi Publik (JKAP), 19(2), 115-131

Horton, D., Alexaki, A., Bennett-Lartey, S., Brice, K. N., Campilan, D., Carden, F., et al. (2013). Evaluating Capacity Development: Experiences From Research And Development Organizations Around The World. ISNAR, CTA, IDRC.

Lupiyoadi, H. (2006). Manajemen Pemasaran Jasa . Jakarta: Salemba Empat.

Nurcholis, H. (2011). Pertumbuhan Dan Penyelenggaraan Pemerintahan
Desa . Jakarta: Erlangga.

Muzwardi, A. (2015). The Analysis of Network Governance in the Investment Development of Free Trade Zone and Free Port ( KPBPB) Batam. JurnalKebijakan Dan Administrasi Publik (JKAP), 19(2), 145-155.

Titi Darmi.(2018). Locally-Generated Revenue as A Capacity Parameters of New Regional Autonomy Management.Jurnal Kebijakan Dan Administrasi Publik (JKAP), 22(1), $1-13$

Wibawati, Y. T. (2015). Kapasitas Badan Usaha Milik Desa Dalam Pengelolaan Potensi Desa (Studi Pada Bumdes Desa Bleberan Kecamatan Playen Kabupaten Gunungkidul Dalam Pengelolaan Potensi Wisata Desa). Repository Perpustakaan Pusat UGM.

York, P. (2010). The Sustainability Formula: How Nonprofit Organizations Can Thrive in the. New York: TCC Group 